\title{
ZANESLJIVOST HIDROGEOGRAFSKIH METOD OCENJEVANJA NEMERJENIH OBDOBNIH PRETOKOV V SLOVENIJI
}

\author{
Tajan Trobec \\ Oddelek za geografijo, Filozofska fakulteta Univerze v Ljubljani \\ Aškerčeva 2, SI-I 000 Ljubljana \\ e-mail: tajant@gmail.com
}

Izvirni znanstveni članek

COBISS 1.01

\section{Izvleček}

Obdobne pretoke na vodotokih, ki niso neposredno vključeni v mrežo vodomernih postaj, je potrebno ocenjevati. Tovrstno ocenjevanje je pomembno predvsem za ugotavljanje razpoložljivih vodnih količin in načrtovanje upravljanja z vodami. V prispevku so predstavljene nekatere možnosti ocenjevanja zanesljivosti ocen obdobnih pretokov, dobljenih s pomočjo hidrogeografskih metod.

Ključne besede: hidrogeografija, ocene pretokov, vodomerne postaje, vodotoki, Slovenija

\section{RELIABILITY OF HYDROGEOGRAPHICAL METHODS OF ESTIMATING NON-MEASURED DISCHARGES IN SLOVENIA}

\begin{abstract}
Mean discharges in a certain period on the watercourses with no established gauging stations need to be estimated. Such estimation is important for determining the availability of the water resources and water management. The article presents some possibilities of estimating the reliability of estimates in a certain period, using the hydrogeographical methods.
\end{abstract}

Key words: hydrogeography, discharge estimates, water gauging stations, watercourses, Slovenia 


\section{UVOD}

Prispevek je nadaljevanje članka z naslovom Hidrogeografske metode ocenjevanja nemerjenih obdobnih pretokov $v$ Sloveniji, v katerem so hidrogeografske metode ocenjevanja nemerjenih obdobnih pretokov podrobneje predstavljene (Trobec 2008). Kljub relativno gosti mreži vodomernih postaj na slovenskih vodotokih so mnogi iz nje izvzeti. Pri ocenjevanju njihovihobdobnih pretokovselahkoopremonapodatkeopretokihnaprimerjalnihvodomernih postajah z vodotokov v bližnjih porečjih, za katere predvidevamo, da imajo podobne odtočne značilnosti. Pri tovrstnem ocenjevanju obdobnih pretokov predpostavimo, da so specifični odtoki na sosednjih porečjih A in B, na nekem geografsko zaokroženem območju, med seboj dovolj podobni, da lahko s pomočjo podatkov o obdobnih pretokih vodomerne postaje $\mathrm{v}$ porečju A ocenjujemo obdobne pretoke na vodotokih v sosednjem porečju B. To lahko počnemo le ob poznavanju površine vodozbirnega zaledja tako za vodomerno postajo kot tudi za vodotok, kjer obdobne pretoke ocenjujemo. Zanesljivosti ocen obdobnih pretokov so odvisne od številnih dejavnikov, med katerimi so najpomembnejši ustreznost izbire primerjalne vodomerne postaje, kakovost podatkov o pretokih za primerjalno vodomerno postajo ter dolžina podatkovnega niza. Pričujoči prispevek se ukvarja z ocenjevanjem zanesljivosti s pomočjo hidrogeografskih metod ocenjenih obdobnih pretokov.

V članku uporabljamo naslednje količine in njihove okrajšave:

- Pretok vode $(Q)$ je količina vode, ki odteče skozi ovlažen rečni profil na določenem me-

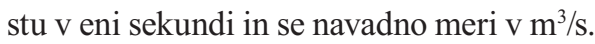

- Povprečni pretok v določenem obdobju $(s Q s)$ predstavlja dolgoletno povprečno količino vode v strugi.

- Obdobni srednji mali $(s Q n p)$ in veliki pretok $(s Q v p)$ opisujeta povprečno količinsko stanje vodotokov ob malih oziroma velikih pretokih; izračunata se $\mathrm{z}$ aritmetično sredino najmanjših oziroma največjih letnih pretokov v določenem obdobju.

- Najmanjši $(n Q n p)$ in največji obdobni pretok (nQvp) predstavljata najmanjšo oziroma največjo količino vode v strugi znotraj določenega obdobja, izmerjeno na dan (lahko tudi več posamičnih dni), ko je bilo v strugi zabeleženo najmanj/največ vode; kadar je znotraj posameznega dneva zabeleženih več meritev, se ne upoštevajo konice, temveč dnevno povprečje.

- Obdobne male (nQnk) oziroma visoke konice $(n Q v k)$ predstavljajo absolutno najmanjše/ največje pretoke, izmerjene $\mathrm{v}$ določenem obdobju.

- Specifični odtok $(q)$ je količina, ki nam pove, koliko vode v povprečju odteče v sekundi z $1 \mathrm{~km}^{2}$ površja ob obdobnem srednjem pretoku $(s Q s)$. Dobimo ga s kvocientom pretoka $(Q)$ in vodozbirnega zaledja $(F)$, navadno ga izražamo z enoto $1 / \mathrm{s} / \mathrm{km}^{2}$.

- $\quad s q n p$ in $s q v p$ sta specifična odtoka ob obdobnih srednjih malih ( $s Q n p)$ oziroma visokih pretokih $(s Q v p)$.

- $\quad n q n p$ in $n q v p$ sta specifična odtoka ob najmanjših (nQnp) oziroma najvišjih obdobnih pretokih (nQvp). 


\section{OPIS PROBLEMATIKE}

Kakovost ocen obdobnih pretokov, ki jih dobimo s hidrogeografskimi metodami ocenjevanja, ni empirično preverljiva. S temi metodami ocenjujemo obdobne karakteristične pretoke $(s Q s, s Q n p, n Q n p, \ldots)$, navadno za obdobje tridesetih let, ki se jih z vzporednimi kontrolnimi dnevnimi, mesečnimi in tudi nekajletnimi kontinuiranimi meritvami pretokov na terenu praviloma ne da učinkovito preverjati. Obdobni pretoki so namreč odvisni predvsem od povprečne količine padavin in izhlapevanja na območju vodozbirnega zaledja določenega vodotoka v opazovanem obdobju (navadno 30 let), medtem ko trenutni pretoki odražajo kompleksnejše součinkovanje več dejavnikov, na primer: reliefa, strmine pobočij, trenutne količine padavin in količine padavin v bližnji preteklosti, oblike in intenzitete padavin (snežne (retinenca), dežne, nalivi, ...), vlage v tleh, nivoja podtalnice, izhlapevanja, prepustnosti geološke podlage in njene sposobnosti zadrževanja vode, infiltracijske sposobnosti tal, tipa vegetacije ipd. Znano je, da povprečna količina padavin zaradi časovne in prostorske spremenljivosti padavin po posameznih dnevih, mesecih in letih niha (Bat in sod. 2003). V praksi to pomeni, da lahko bližnji porečji, ki imata sicer podobno dolgoletno povprečno količino padavin, na določen dan, $\mathrm{v}$ določenem tednu, mesecu ali celo letu prejmeta znatno različno dnevno, mesečno ali letno količino padavin, kar se zrcali v različnih dnevnih, mesečnih in tudi letnih odtokih z obeh porečij. Zaradi tega tudi z nekajletnimi vzporednimi kontrolnimi meritvami ne bi mogli zanesljivo preveriti naše ocene pretokov, še posebej malih in najmanjših obdobnih pretokov, ki praviloma nastopijo le enkrat v 30 letih. Za ocenjevanje zanesljivosti ocenjenih obdobnih pretokov je torej potrebno poseči po metodah posrednega preverjanja, ki so podrobneje predstavljene $\mathrm{v}$ nadaljevanju prispevka.

\section{SPREMENLJIVOST SPECIFIČNIH ODTOKOV PO POSAMEZNIH LETIH MED POTENCIALNIMI PRIMERJALNIMI VODOMERNIMI POSTAJAMI NA PRIMERU POLJANSKE SORE}

Vzemimo za primer porečje Poljanske Sore s pestro geološko zgradbo. Prevladujejo vodoodporne kamnine različnih starosti (glinasti skrilavec, peščenjak in dolomit; Grad 1974), zaradi česar je rečna mreža razvejana in dobro razvita. Denimo, da želimo ocenjevati obdobne pretoke na vodotokih širšega porečja, na potokih Žirovnica, Hobovščica, Kopačnica, Sevniščica, Račeva in Brebovščica. Pretoke na Poljanski Sori spremljata vodomerni postaji Žiri in Zminec, v sosednjih porečjih pa razpolagamo še s podatki vodomernih postaj Železniki na Selški Sori, Cerkno na Cerknici, Dvor na Gradaščici ter Razori na Šujici (slika 1). Omenjene vodomerne postaje bi nam pri ocenjevanju obdobnih pretokov na izpostavljenih vodotokih služile kot potencialne primerjalne vodomerne postaje.

Na spodnjih grafikonih (sliki 2 in 3) sta prikazana q,i in qnp,i po posameznih letih za vodomerne postaje Cerkno, Razori, Žiri, Dvor, Železniki in Zminec, s katerimi bi lahko ocenjevali pretoke na pritokih Poljanske Sore. Iz grafikonov je razvidno, kako se specifični odtoki na posameznih postajah od leta do leta spreminjajo. Že bežna primerjava grafikonov razkrije, da je korelacija med $q$-ji na posameznih postajah sosednjih vodotokov (Cerknica 
Slika 1: Potencialne primerjalne vodomerne postaje za ocenjevanje obdobnih pretokov na pritokih Poljanske Sore

Figure 1: Potential corresponding neighboring gauging stations used for estimating the discharges on the Poljanska Sora tributary streams

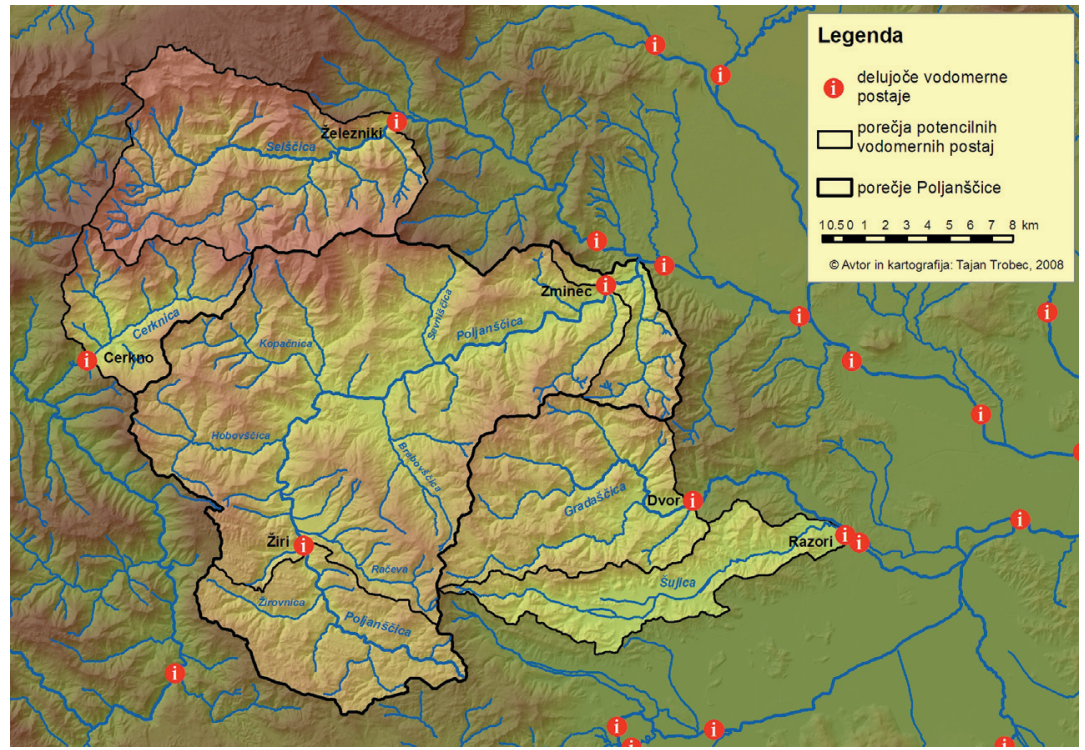

Vir/source: Geodetska uprava RS, Agencija RS za okolje

in Selška Sora na eni strani ter Gradaščica, Šujica in Poljanska Sora v Žireh na drugi strani) značilno večja od korelacije med $q n p$-ji, saj se vsakoletni najnižji pretoki na posameznih postajah pojavljajo $\mathrm{v}$ različnih obdobjih in so posledica lokalno-časovnega součinkovanja različnih fizičnogeografskih značilnosti posameznih porečij (relief, nadmorska višina, vremenske razmere, značilnosti geološke podlage ipd.). Iz tega sledi, da bi bile ocene $s Q n p$ in še zlasti $n Q n p$, kjer ne razpolagamo s podatki vodomernih postaj, še manj zanesljive kot ocene $s Q s$. Napake v ocenah se manjšajo sorazmerno z dolžino opazovalnega niza primerjalne vodomerne postaje, saj se $\mathrm{z}$ večletnimi povprečji razlike $\mathrm{v}$ specifičnih odtokih med sosednjimi vodotoki do neke mere zgladijo.

$\mathrm{Na}$ spodnjih grafikonih je prikazana korelacija $q$-jev (slika 4) ter qnp-jev (slika 5) po posameznih letih med sosednjima rekama, Gradaščici v Dvoru in Šujici v Razorih, v obdobju 1979-2000, ko sta vodomerni postaji delovali hkrati. Pri $q$-jih je korelacija med vodomernima postajam Dvor in Razori relativno visoka in znaša 0,83 , pri qnp-jih pa je bistveno šibkejša in znaša komaj 0,43 . Vzroke za šibko korelacijo qnp,i-jev med vodomernima postajama Dvor in Razori gre iskati v razmaknjenosti porečij (ta v povprečju znaša približno $6 \mathrm{~km}$ ), različni povprečni nadmorski višini in lokalno-časovni porazdelitvi padavin, različnih strminah pobočij, značilnostih geološke podlage itd. Opisana primera potrjujeta predhodne trditve o tem, da tudi z večletnimi kontrolnimi meritvami ocen pretokov (še zlasti nizkih pretokov), dobljenih s hidrogeografskimi metodami, verjetno ne bi mogli dovolj zanesljivo preveriti. 
Slika 2: Vrednosti q,i za posamezna leta za vodomerne postaje Cerkno, Razori, Žiri, Dvor, Železniki in Zminec v obdobju 1971-2000

Figure 2: Annual values of q,i for the Cerkno, Razori, Žiri, Dvor, Železniki and Zminec gauging stations in the period 1971-2000

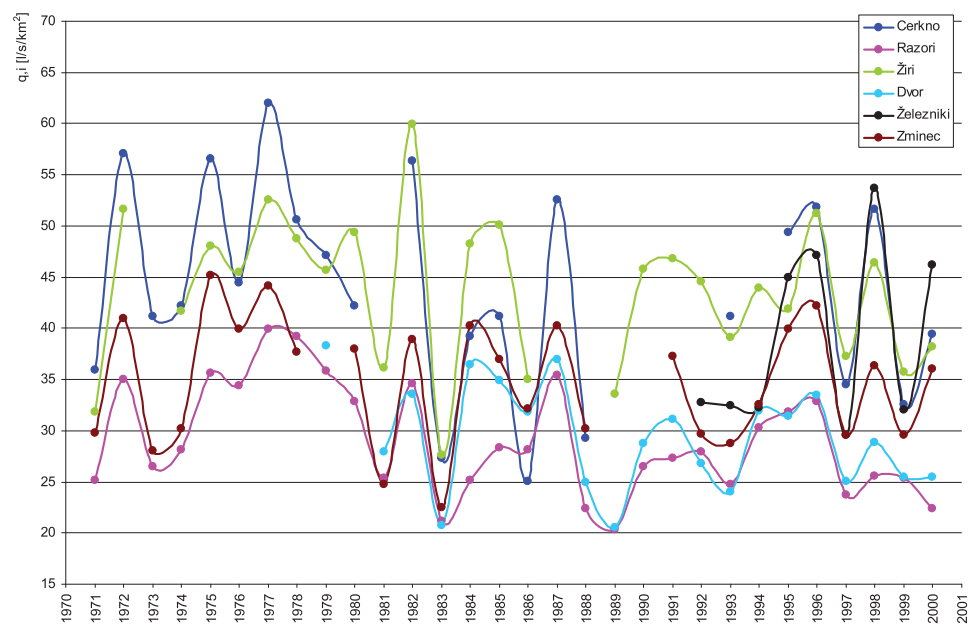

Vir/source: Arhiv sektorja za hidrologijo, urad za monitoring, Agencija RS za okolje

Slika 3: Vrednosti qnp, i za posamezna leta za vodomerne postaje Cerkno, Razori, Žiri, Dvor, Železniki in Zminec v obdobju 1971-2000

Figure 3: Annual values of qnp, i for the Cerkno, Razori, Žiri, Dvor, Železniki and Zminec gauging stations in the period 1971-2000

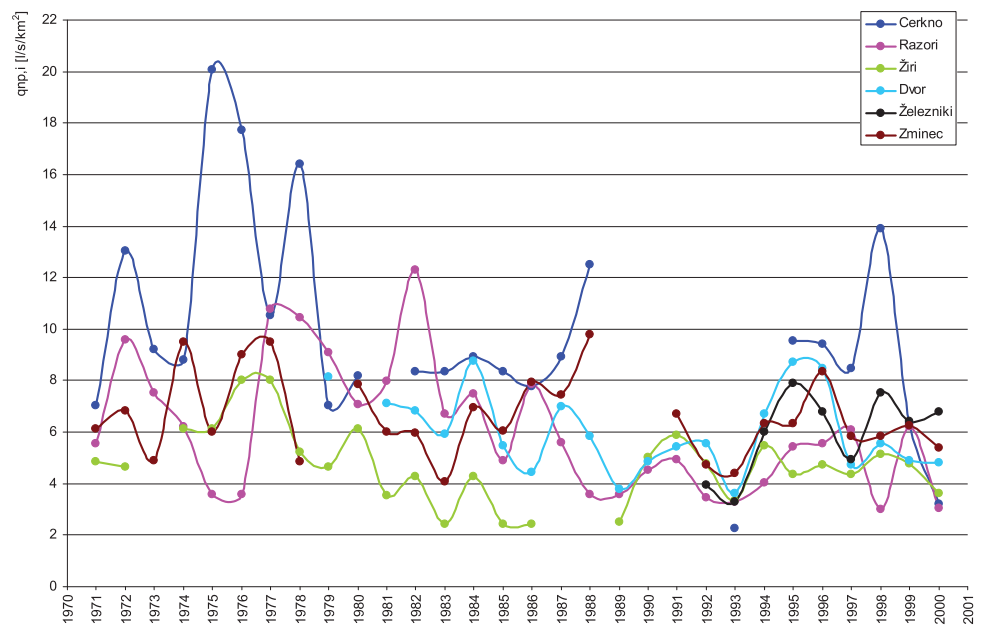

Vir/source: Arhiv sektorja za hidrologijo, urad za monitoring, Agencija RS za okolje 
Slika 4: Korelacija med q-ji za vodomerni postaji Dvor in Razori v obdobju 1971-2000 Figure 4: Correlation between $q$-s for the Dvor and Razori gauging stations in the period 1971-2000

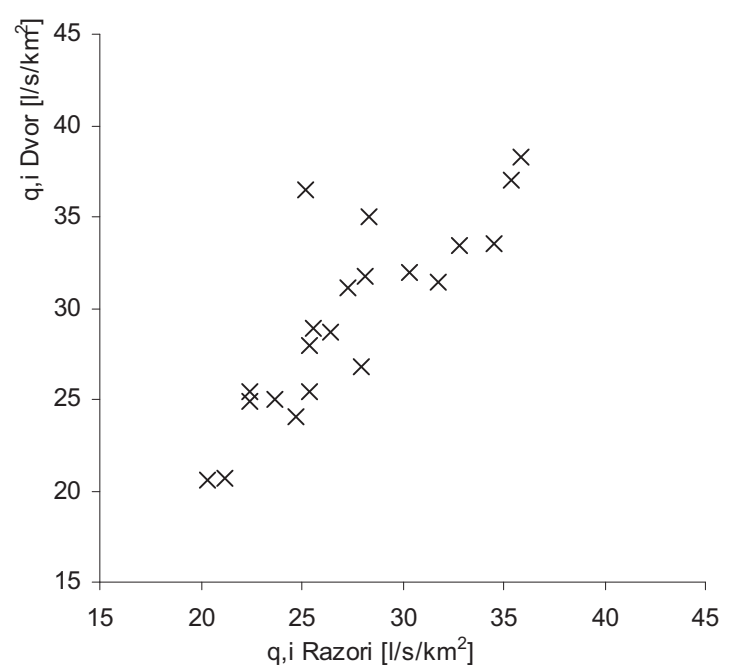

Vir/source: Arhiv sektorja za hidrologijo, urad za monitoring, Agencija RS za okolje

Slika 5: Korelacija med qnp-ji za vodomerni postaji Dvor in Razori v obdobju 1971-2000 Figure 5: Correlation between qnp-s for the Dvor and Razori gauging stations in the period 1971-2000

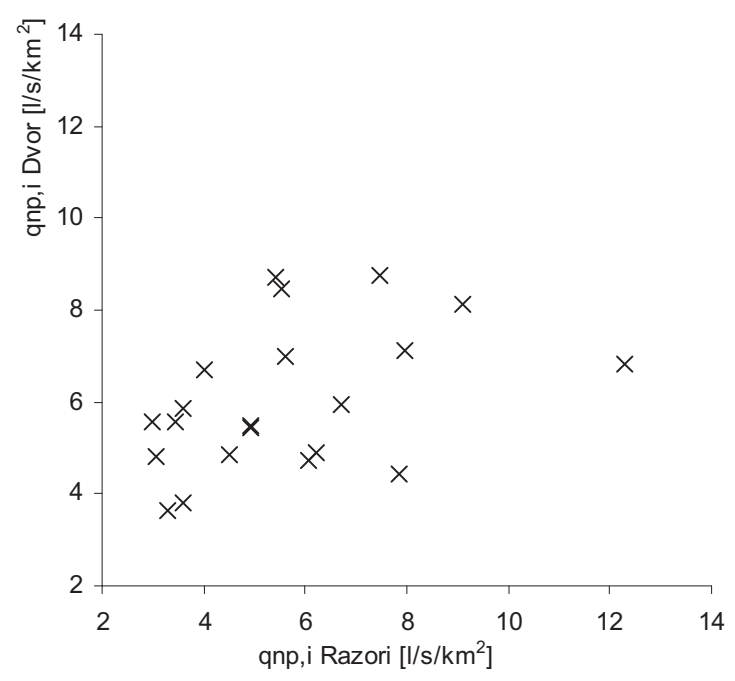

Vir/source: Arhiv sektorja za hidrologijo, urad za monitoring, Agencija RS za okolje 


\section{PREVERJANJE OCENJENIH OBDOBNIH PRETOKOV S POMOČJO OPUŠČENIH VODOMERNIH POSTAJ NA PRIMERU POHORSKIH PRITOKOV DRAVE}

Preučili smo možnost, da bi ocene obdobnih pretokov preverjali posredno, s pomočjo podatkov opuščenih vodomernih postaj, ki jih hranijo v arhivu Agencije RS za okolje. Podrobneje bomo predstavili primer preverjanja ocen pretokov na Velki (slika 7).

Na Velki je med leti 1958 in 1974 delovala vodomerna postaja Lehen. Na žalost je niz podatkov preveč zastarel, da bi ga lahko danes uporabili za ocenjevanje pretokov na Velki, saj pri tem stremimo k čim popolnejšemu podatkovnemu nizu znotraj obdobja 1971-2000, lahko pa primerjamo podatke s tistimi na vodomerni postaji Ruta na Radoljni, ki jo danes uporabljamo za ocenjevanje pretokov na celotnem območju severnih pobočij Pohorja. Vodozbirni zaledji Radoljne in Velke imata precej podobne geografske poteze. Oba vodotoka izvirata $\mathrm{v}$ številnih potočkih na oligocenskih magmatskih kamninah tik pod vršnimi deli Pohorja na nadmorski višini med 1400 in $1500 \mathrm{~m}$. Tok nadaljujeta čez metamorfne kamnine devonske starosti. V višini Lovrenca na Pohorju oziroma Ribnice na Pohorju prečkata pas miocenskih usedlin ter si nazadnje utreta pot do izliva v Dravo, ponovno čez pas devonskih metamorfnih kamnin (Mioč in sod. 1977), v katero se izlivata na nadmorski višini okoli 300 m. Glede na to, da gre za sosednji porečji, lahko sklepamo na podobno količino padavin. Ocenjena vrednost povprečne količine padavin za vodozbirno zaledje vodomerne postaje Ruta v obdobju 1961-1990 je 1467 mm (Kolbezen, Pristov 1998). Obe porečji sta redko poseljeni, posegi v naravni odtok voda pa so zanemarljivi. Odtočne značilnosti obeh rek med seboj najlažje primerjamo, če izračunamo $q$, sqnp in nqnp za obe postaji, in sicer v času, ko sta ti delovali hkrati (1973-1974) (slika 6, preglednica 1). Razvidno je, da sta postaji v tem obdobju beležili različne odtočne značilnosti. Skupaj je v Lehnu glede na velikost vodozbirnega zaledja odteklo približno $12 \%$ več vode kot v Ruti, sqnp ter nqnp pa sta bila večja v Ruti, in sicer za $40 \%$. Razlika v $q$ je sprejemljiva, saj se nahaja znotraj okvira napak, ki se pojavljajo pri merjenju pretokov in določanju razvodnic, razlike $\mathrm{v} s q n p$ in $n q n p$ pa so presenetljivo velike.

Glede na to, da je Ruta edina postaja z ustreznim podatkovnim nizom na območju severnega dela Pohorja, bi jo kot primerjalno postajo uporabili tudi pri ocenjevanju pretokov na Vuhreščici in Lobnici. Za omenjeni reki obstajajo podatki iz opuščenih vodomernih postaj Orlica na Vuhreščici in Ruše na Lobnici, ki imata sicer zastarela podatkovna niza, sta pa delovali med leti 1973 in 1974, tako da lahko njune podatke primerjamo s podatki Rute in Lehna v tem obdobju. Izkaže se, da Orlica in Ruše v letih 1973 in 1974 izkazujeta skoraj 25 \% večji $q$ kot je izračunan v Ruti. V Rušah sta bila večja tudi sqnp in $n q n p$, in sicer sqnp za $25 \%$ in nqnp za $18 \%$, medtem ko je bil v Orlici sqnp večji za $42 \%$, nqnp pa je bil za $14 \%$ manjši kot v Ruti. Na Radoljni se je najnižji pretok v obeh letih pojavil decembra, na Lobnici avgusta. Najnižji pretok leta 1973 se je na Vuhreščici in Velki pojavil avgusta, leta 1974 na Vuhreščici junija ter na Velki decembra.

Gornji rezultati so, še posebej ko gre za male pretoke, med seboj precej različni. Radoljna in Velka v splošnem izkazujeta nižje specifične odtoke kot Vuhreščica in Lobnica, 
kar je lahko posledica več dejavnikov, najverjetneje pa gre za kombinacijo različnih lokalnih vremenskih razmer v obravnavanem obdobju ter za neustrezno kratko obdobje le dveh let, znotraj katerih smo primerjali izmerjene vrednosti pretokov. Menimo, da v obravnavanem primeru zaradi prekratkega vzporednega podatkovnega niza na postajah ni moč ovrednotiti zanesljivosti ocen pretokov na Velki.

Preglednica 1: Hidrološke značilnosti za vodomerne postaje Ruta, Lehen, Orlica in Ruše v obdobju 1973-1974

Table 1: Hydrological characteristics for the Ruta, Lehen, Orlica and Ruše gauging stations in the period 1973-1974

\begin{tabular}{|l|c|c|c|c|c|c|c|c|}
\hline $\begin{array}{l}\text { Vodomerna } \\
\text { postaja }\end{array}$ & $\mathbf{N i z}$ & $\mathbf{F}\left[\mathbf{k m}^{2}\right]$ & $\mathbf{s Q s}\left[\mathbf{m}^{\mathbf{3}} / \mathbf{s}\right]$ & $\begin{array}{c}\mathbf{s Q n p} \\
{\left[\mathbf{m}^{\mathbf{3}} / \mathbf{s}\right]}\end{array}$ & $\begin{array}{c}\mathbf{n Q n p} \\
{\left[\mathbf{m}^{\mathbf{3}} / \mathbf{s}\right]}\end{array}$ & $\mathbf{q}\left[\mathbf{l} / \mathbf{s} / \mathbf{k m}^{\mathbf{2}}\right]$ & $\begin{array}{c}\mathbf{s q n p}[\mathbf{l} / \mathbf{s} / \\
\left.\mathbf{k m}^{\mathbf{2}}\right]\end{array}$ & $\begin{array}{c}\mathbf{n q n p} \\
{\left[\mathbf{l} / \mathbf{s} / \mathbf{k m}^{\mathbf{2}}\right]}\end{array}$ \\
\hline RUTA & $1973-1974$ & 74,14 & 2,150 & 0,850 & 0,800 & 29,0 & 11,46 & 10,79 \\
\hline LEHEN & $1973-1974$ & 46,69 & 1,512 & 0,380 & 0,360 & 32,4 & 8,14 & 7,71 \\
\hline ORLICA & $1973-1974$ & 39,8 & 1,442 & 0,650 & 0,370 & 36,2 & 16,33 & 9,30 \\
\hline RUŠE & $1973-1974$ & 42,56 & 1,521 & 0,610 & 0,540 & 35,7 & 14,33 & 12,69 \\
\hline
\end{tabular}

Vir/source: Arhiv sektorja za hidrologijo, urad za monitoring, Agencija RS za okolje

Slika 6: Vrednosti q, sqnp in nqnp za vodomerne postaje Ruta, Lehen, Orlica in Ruše v obdobju 1973-1974

Figure 6: The values q, sqnp and nqnp for the Ruta, Lehen, Orlica and Ruše gauging stations in the period 1973-1974

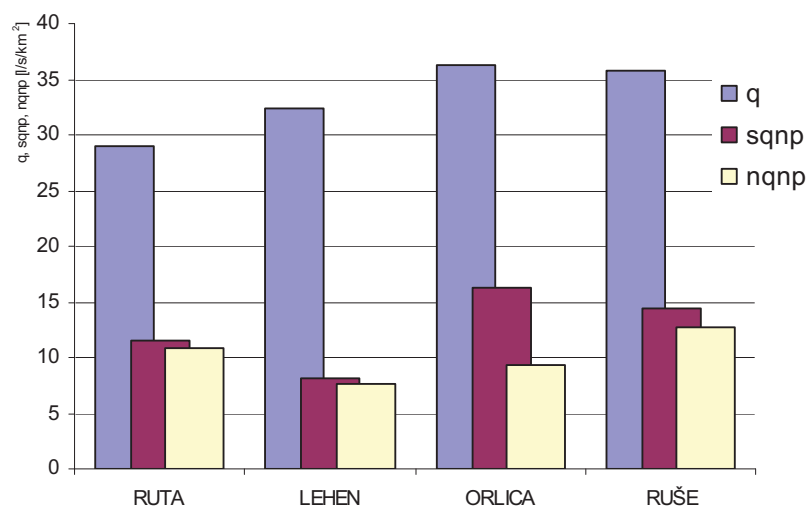

Vir/source: Arhiv sektorja za hidrologijo, urad za monitoring, Agencija RS za okolje

Na podobne težave naletimo pri večini ostalih opuščenih vodomernih postaj, saj se njihovi zastarani podatkovni nizi, navadno le v manjši meri prekrivajo s podatki kasneje vzpostavljenih postaj, zaradi česar je primerjava med njimi otežena. Mnoge izmed opuščenih postaj so delovale le nekaj let. Pri nekaterih niti niso bile določene pretočne krivulje in tako razpolagamo le s podatki o vodostajih, iz katerih zaradi spremenjenih razmer v strugi (erozija, akumulacija) danes ne moremo rekonstruirati pretokov iz časa, ko so te postaje delovale. 
Posredno preverjanje ocen pretokov, dobljenih s hidrogeografskimi metodami, s pomočjo opuščenih vodomernih postaj zaradi opisanih omejitev navadno ni mogoče, so pa podatki o pretokih z opuščenih vodomernih postaj dobrodošel vir informacij, ki ga kljub po večini starejšim podatkovnim nizom nikakor ne gre kategorično zavreči. Kadar pri posrednem preverjanju vzporednih nizov podatkov opuščene in primerjalne vodomerne postaje naletimo na večja odstopanja, ta lahko opozorijo na morebitno nepravilnost naše ocene.

\section{Slika 7: Porečja Vuhreščice, Velke, Radoljne in Lobnice}

Figure 7: The Vuhreščica, Velka, Radoljna and Lobnica river basins

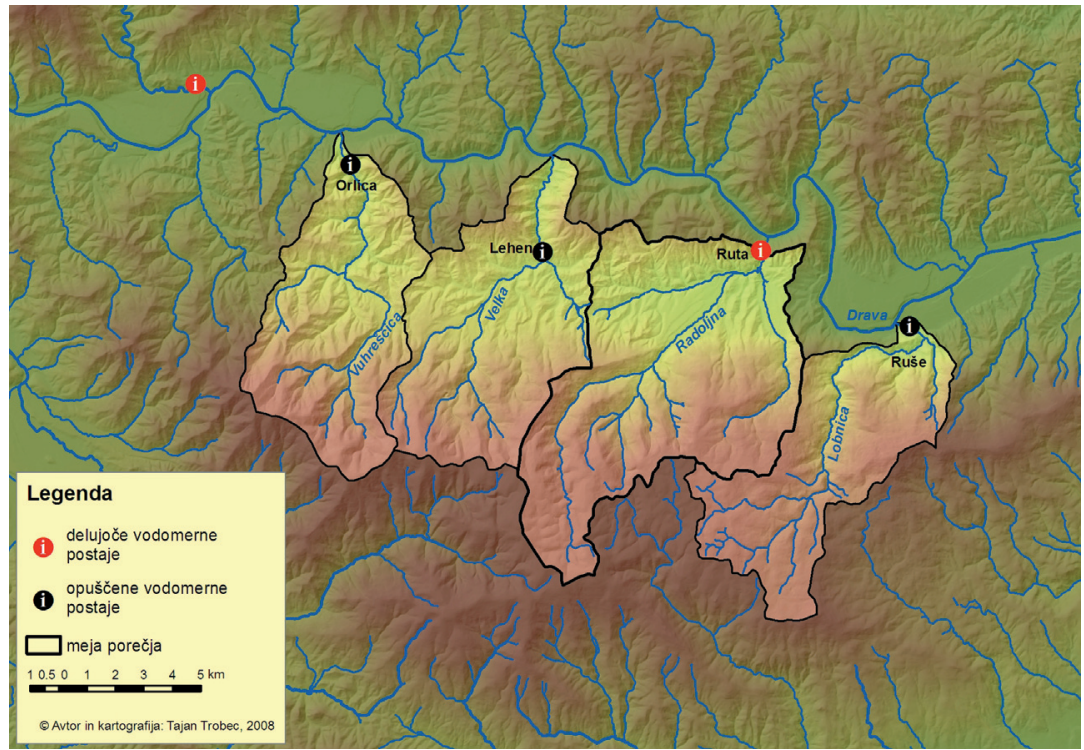

Vira/sources: Geodetska uprava RS; Agencija RS za okolje

\section{PREVERJANJE OCENJENIH OBDOBNIH PRETOKOV S PRIMERJAVO ODTOČNIH ZNAČILNOSTI SOSEDNJIH POREČIJ}

Ugotavljamo, da pravzaprav nimamo učinkovitega in zanesljivega načina za preverjanje zanesljivosti ocenjenih pretokov. Če bi bila mreža vodomernih postaj gostejša in bi hipotetično razpolagali z enakim nizom podatkov kot za Radoljno na primer tudi za Velko, bi lahko neposredno primerjali $q$, sqnp in nqnp za obe reki. Če bi bile izračunane vrednosti znotraj neke definirane dopustne tolerance odstopanja (morda 10-20\%), bi to pomenilo, da so značilnosti porečij, ki vplivajo na odtok, med seboj primerljive, razlike v odtoku pa zanemarljive. Hidrogeografske metode ocenjevanja pretokov bi lahko v takšnem primeru privzeli kot dovolj zanesljive, da z njimi zaradi domnevno podobnih fizično- in družbenogeografskih značilnosti porečij, ki vplivajo na odtok, ocenjujemo pretoke tudi na Vuhreščici in 
Lobnici. Ker pa so vodomerne postaje $\mathrm{z}$ vidika ocenjevanja nemerjenih pretokov razporejene zelo racionalno, tovrstne primerjave navadno niso mogoče; redke izjeme so na primer pari/ skupine vodomernih postaj Dvor in Razori; Preska in Kokra; Solčava in Luče; Gabrke, Škale (Ljubela) in Škale (Lepena); Velenje in Polže; Zamušani in Pristava; Cankova, Polana in Martjanci; Hodoš, Središče in Kobilje; Tolmin in Bača pri Modreju ter Kršovec in KalKoritnica.

Z zgoraj naštetimi vodomernimi postajami lahko do neke mere posredno preverimo zanesljivost ocenjevanja nemerjenih pretokov. Postaje znotraj posameznih parov/skupin so locirane na vodotokih, katerih porečja so v neposredni soseščini oziroma se držijo skupaj. Porečja vodotokov znotraj posameznih parov/skupin postaj imajo po naši oceni podobne fizičnogeografske značilnosti (relief, nadmorska višina, količina in razporeditev padavin, geološka podlaga, ...), zaradi česar lahko sklepamo na podobne specifične odtoke. To pomeni, da bi teoretično lahko s podatki o obdobnih pretokih ene postaje znotraj para/skupine ocenjevali obdobne pretoke na drugi/drugih postajah znotraj istega para/skupine. Ocene bi nato primerjali s pravimi vrednostmi in ugotovili, za koliko odstopajo od realnih pretokov. Nepotrebnemu računanju pretokov se lahko izognemo, tako da med seboj primerjamo le specifične odtoke in ugotovimo, za koliko se vrednosti $q$, sqnp in nqnp na posameznih postajah znotraj istega para/skupine medsebojno razlikujejo. Pri tem je pomembno, da podatke o pretokih primerjamo zgolj za tista leta v obdobju 1971-2000, ko so postaje znotraj posameznega para/skupine delovale sočasno.

Vodomerni postaji Dvor in Razori merita pretoke na Gradaščici in Šujici, ki odmakata južna pobočja Polhograjskega hribovja. Primerjali smo ju v letih 1979 ter 1981-2000. Njuni porečji sestojita deloma iz karbonatnih kamnin (med katerimi prevladuje dolomit), deloma iz permokarbonskih glinavcev. Specifični odtoki, še zlasti $q$ in $s q n p$, so na obeh postajah podobni, tako da bi obdobne pretoke na eni reki lahko dokaj natančno in zanesljivo ocenjevali s pomočjo podatkov za postajo na drugi reki. V Dvoru so $q$ za $8 \%$, sqnp za $7 \%$ in $n q n p$ za $21 \%$ pričakovano večji kot v Razorih (slika 8, preglednica 2), saj je porečje Gradaščice višje in zato bolj namočeno od porečja Šujice. Ugotavljamo, da lahko zaradi podobnih vrednosti specifičnih odtokov na vodomernih postajah Dvor in Razori metodo ocenjevanja nemerjenih pretokov na južnih pobočjih Polhograjskega hribovja privzamemo kot zanesljivo. Pri ocenjevanju pretokov na sosednjih vodotokih bi izbrali tisto postajo, za katero bi na osnovi preučitve fizično- in družbenogeografskih dejavnikov predvidevali, da ima podobnejše specifične odtoke.

Vodomerni postaji Preska in Kokra merita pretoke na Tržiški Bistrici in Kokri. Primerjali smo ju v letih 1971-2000. Tržiška Bistrica odmaka južna pobočja Karavank, Kokra pa zahodni del Kamniško-Savinjskih Alp. Porečji sta primerljivi po nadmorski višini in količini padavin, ki jo ocenjujemo na 1600-2000 mm na letni ravni. Geološka zgradba porečij je precej zapletena, delež karbonatnih kamnin pa je večji v porečju Kokre. V Preski je $q$ za $6 \%$, sqnp za $54 \%$ in nqnp za $111 \%$ večji kot v Kokri, kar je presenetljivo veliko (slika 8, preglednica 2). Podatki kažejo na podpovršinski odtok v Kokri, ki ob nizkih vodostajih pride še bolj do izraza. Ocene nemerjenih pretokov $s Q n p$ in $n Q n p$, osnovane na vodomerni postaji Kokra, bi bile znatno nižje od ocen, osnovanih na vodomerni postaji Preska. Metodo ocenjevanja 
nemerjenih pretokov za $s Q s$ lahko zaradi razmeroma majhnih razlik v $q$ privzamemo za ustrezno, za $s Q n p$ in $n Q n p$ pa zaradi velikih razlik v sqnp in $n q n p$ kot neustrezno. Pretoke na pritokih Kamniške Bistrice bi bilo posledično morda bolj smotrno ocenjevati na podlagi odtočnih značilnosti Tržiške Bistrice v Preski.

Vodomerni postaji Solčava in Luče merita pretoke na Savinji in Lučnici. Primerjali smo ju v letih 1971-1973, 1976-1982 in 1984-2000. Savinja v Solčavi odmaka severovzhodni, Lučnica pa jugovzhodni del Kamniško-Savinjskih Alp. Porečje Savinje nad Solčavo je višje in manj namočeno od porečja Lučnice. Ocenjujemo, da porečje Savinje na letni ravni prejme okoli $1900 \mathrm{~mm}$, porečje Lučnice pa okoli $1700 \mathrm{~mm}$ padavin. Kljub manj padavinam sta v Lučah $q$ za $25 \%$ ter sqnp za $13 \%$ večja kot v Solčavi, medtem ko je nqnp presenetljivo večji v Solčavi, in sicer za 108 \% (slika 8, preglednica 2). Razlike v specifičnih odtokih so verjetno posledica podpovršinskega odtoka Savinje v Solčavi (Kolbezen, Pristov 1998). Zanimivo je dejstvo, da je $n Q n p$, ki se je v Lučah pojavil januarja $1989\left(0,065 \mathrm{~m}^{3} / \mathrm{s}\right)$, bistveno odstopal od ostalih najnižjih letnih pretokov za posamezna leta. Drugi najnižji letni pretok $\left(0,12 \mathrm{~m}^{3} / \mathrm{s}\right)$ je bil denimo skoraj za $100 \%$ večji. Po drugi strani v Solčavi $n Q n p\left(0,15 \mathrm{~m}^{3} / \mathrm{s}\right)$ ni bistveno odstopal od ostalih najnižjih pretokov posameznih let. Drugi najnižji pretok v Solčavi je bil $0,17 \mathrm{~m}^{3} / \mathrm{s}$, tretji $0,18 \mathrm{~m}^{3} / \mathrm{s}$, četrti $0,22 \mathrm{~m}^{3} / \mathrm{s}$ itd. Iz opisanega primera je razvidno, kako je dolžina opazovalnega niza pomembna za zajem lokalno-časovno ekstremnih pretokov, kot je bil ta v Lučah. Če bi denimo iz analize pretokov na Solčavi in v Lučah izvzeli leto 1989, bi bil nqnp na obeh postajah skoraj enak, tako pa se sedaj razlikuje za več kot $100 \%$. Domnevamo, da se porečji Savinje v Solčavi in Lučnice v pokrajinski sestavi med seboj preveč razlikujeta, da bi lahko z odtočnimi značilnostmi ene reke uspešno ocenjevali pretoke na drugi, še zlasti, ko gre za ocenjevanje $n Q n p$.

Slika 8: Vrednosti q, sqnp in nqnp za vodomerne postaje Dvor, Razori, Preska, Kokra, Solčava, Luče v obdobju 1971-2000

Figure 8: Values q, sqnp and nqnp for the Dvor, Razori, Preska, Kokra, Solčava and Luče gauging stations in the period 1971-2000

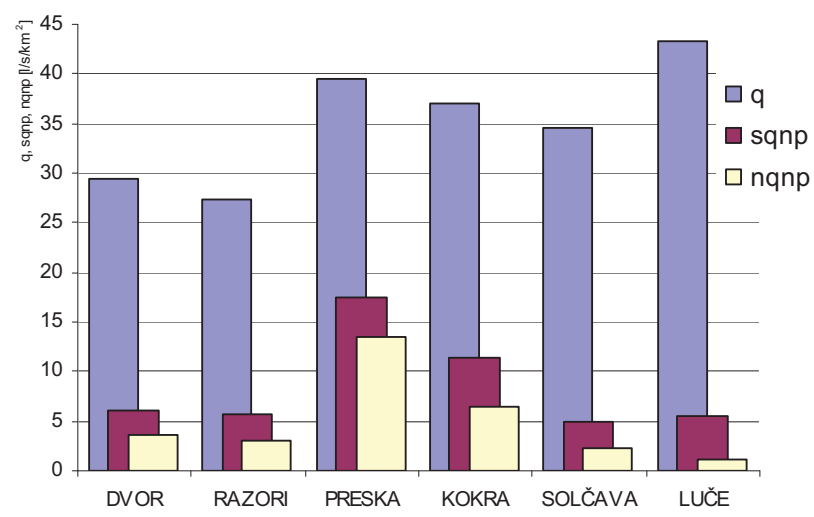

Vir/source: Arhiv sektorja za hidrologijo, urad za monitoring, Agencija RS za okolje 
Vodomerna postaja Gaberke meri pretoke na Velunji, Škale pa na Ljubeli in Lepeni. Med seboj smo jih primerjali v letih 1986-2000. Vodotoki odmakajo južna pobočja Karavank severno od Velenjske kotline. Med omenjenimi postajami najbolj izstopa vodomerna postaja Gaberke, saj ima bistveno večje odtočne količnike od obeh postaj v Škalah (slika 9, preglednica 2). Vrednost $q$ na Ljubeli predstavlja dobri $2 / 3$, na Lepeni pa slabi $2 / 3 q$ na Velunji, vrednost sqnp na Ljubeli predstavlja $40 \%$, na Lepeni $23 \%$ sqnp na Velunji, vrednost $n q n p$ na Ljubeli predstavlja $58 \%$, na Lepeni pa le še $13 \%$ nqnp na Velunji. Velunja s svojim porečjem posega daleč proti zahodu, kjer so višje nadmorske višine in posledično tudi več padavin, zato višji $q$, sqnp in nqnp ne presenečajo. Presenečajo pa razlike med specifičnimi odtoki na Ljubeli in Lepeni, še posebej med sqnp in nqnp, saj je sqnp na Ljubeli za $75 \%$, nqnp pa kar za 3,3-krat večji kot na Lepeni. Razloge za tako velike razlike v specifičnih odtokih na obeh postajah v Škalah gre iskati predvsem v majhnosti porečij in posledično majhnih pretokih, kjer že razlike nekaj litrov $\mathrm{v}$ pretokih lahko pomenijo nekajkratno povečanje/zmanjšanje sqnp in nqnp. Zaradi velikih razlik med sqnp in nqnp sklepamo, da je metoda ocenjevanja nemerjenih pretokov na obravnavanem območju za ocenjevanje sQnp in $n Q n p$ neustrezna.

Vodomerni postaji Velenje in Polže merita pretoke na Paki in Hudinji. Primerjali smo ju v letih 1978-1989. Obe reki izvirata na Pohorju in se na svojem toku preko vzhodnih Karavank prebijeta do nižje ležečih delov porečja, Paka proti Velenju in Hudinja proti Vojniku. Porečji sta primerljivi po nadmorski višini in geološki sestavi. Na podlagi padavinske karte (Cegnar 2003) ocenjujemo, da porečje Hudinje v povprečju prejme okoli $100 \mathrm{~mm}$ manj padavin na letni ravni. Na Paki je $q$ za $5 \%$ večji kot na Hudinji, medtem ko sqnp in $n q n p$ v Velenju predstavljata le $44 \%$ oziroma $36 \%$ sqnp in nqnp v Polžah (slika 9, preglednica 2). Velike razlike $\mathrm{v}$ pretokih ob majhnih vodostajih presenečajo in nakazujejo na znaten podpovršinski pretok Pake v Velenju. Del razlike je lahko tudi posledica tega, da smo odtočne značilnosti v Velenju in Polžah primerjali zgolj znotraj dvanajstletnega obdobja (1978-1989), v katerem je Paka v Velenju izkazovala bistveno nižji sQnp $\left(0,128 \mathrm{~m}^{3} / \mathrm{s}\right)$ kot v obdobju 1990-2000, ko ji bil sQnp z 0,278 m³/s večji kar za $117 \%$. Na žalost s podatki za Pako v Polžah v tem obdobju ne razpolagamo. Metodo ocenjevanja nemerjenih pretokov za $s Q s$ lahko privzamemo za ustrezno, za $s Q n p$ in $n Q n p$ pa zaradi velikih razlik v sqnp in nqnp v Velenju in Polžah kot neustrezno.

Vodomerni postaji Zamušani in Pristava merita pretoke na Pesnici in Ščavnici. Primerjali smo ju v letih 1971-2000. Pesnica odvaja vodo iz zahodnih, Ščavnica pa iz vzhodnih delov Slovenskih goric. Slovenske gorice sestojijo iz različnih miocenskih in pliocenskih sedimentov (prod, pesek, lapor, glina, ...). Razprostirajo se med 250 in 300 m nadmorske višine ter v povprečju prejmejo med 900 in $1100 \mathrm{~mm}$ padavin na letni ravni. V splošnem so v Zamušanih specifični odtoki večji od tistih v Pristavi, in sicer $q$ za $35 \%$, sqnp za $47 \%$ ter nqnp za $150 \%$ (slika 9, preglednica 2). Kljub temu, da je zaradi približno $100 \mathrm{~mm}$ večje količine padavin v zahodnem delu Slovenskih goric na Pesnici pričakovati večje specifične odtoke, tako velika razlika, še posebej pri malih pretokih, vseeno preseneča. Domnevamo, da se odtočne značilnosti Pesnice in Ščavnice med seboj preveč razlikujejo, da bi s podatki o pretokih ene reke lahko uspešno ocenjevali pretoke na drugi, še zlasti pri ocenjevanju $n Q n p$. 
Slika 9: Vrednosti q, sqnp in nqnp za vodomerne postaje Gaberke, Škale (Ljubela), Škale (Lepena), Velenje, Polže, Zamušani in Pristava v obdobju 1971-2000

Figure 9: Values q, sqnp and nqnp for the Gaberke, Škale (Ljubela), Škale (Lepena), Velenje, Polže, Zamušani and Pristava gauging stations in the period 1971-2000

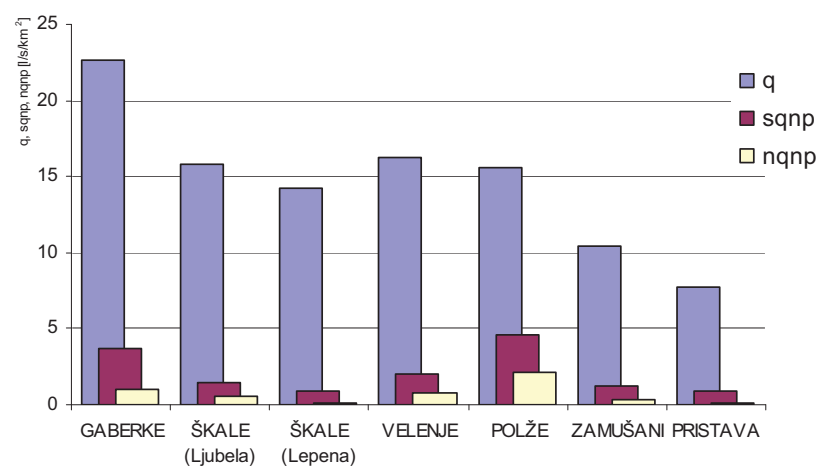

Vir/source: Arhiv sektorja za hidrologijo, urad za monitoring, Agencija RS za okolje

Vodomerne postaje Cankova, Polana in Martjanci merijo pretoke na Kučnici, Ledavi in Martjanskem potoku. Vsi trije vodotoki odmakajo zahodna pobočja Goričkega. Vodomerne postaje Hodoš, Središče in Kobilje merijo pretoke na Veliki Krki, Ivanjševskem potoku in Kobiljskem potoku. Potoki odmakajo vzhodne dele Goričkega. Cankovo, Polano in Martjance smo primerjali v letih 1972 in 1985-2000, Hodoš, Središče in Kobilje pa v letih 1986-2000. Goričko sestoji iz različnih pliocenskih odkladnin (prod, pesek, glina, ...). Dviga se do okoli $350 \mathrm{~m}$ visoko in v povprečju prejme okoli $800 \mathrm{~mm}$ padavin. Vodomerne postaje so med seboj primerljive v vrednostih $q$, ki je najmanjši v Hodošu in največji v Cankovi. V splošnem je razvidno, da imajo zaradi nekoliko večje količine padavin vodotoki na zahodnem Goričkem za spoznanje višje povprečne specifične odtoke. Drugače je pri sqnp in nqnp, kjer med postajami ni pravzaprav nikakršnega ujemanja (slika 10, preglednica 2). Slednje ne preseneča, saj je pri tako majhnih oziroma ničnih malih pretokih (Cankova 1 1/s, Polana 4 1/s, Martjanci, $01 / \mathrm{s}, . .$.$) le-te praktično nemogoče zanesljivo izmeriti. Pri takih vrednostih že razlike nekaj$ litrov v pretoku lahko pomenijo nekajkratne vrednosti sqnp in nqnp. Metodo ocenjevanja nemerjenih pretokov za $s Q s$ lahko privzamemo za ustrezno, za $s Q n p$ in $n Q n p$ pa zaradi velikih razlik v sqnp in nqnp med posameznimi postajami kot neustrezno.

Vodomerni postaji Tolmin in Bača pri Modreju merita pretoke na Tolminki in Bači. Primerjali smo ju v letih 1971-1995 in 1997-2000. Reki odmakata južna pobočja Julijskih Alp med Bogatinom in Koblo. Razmerja med q, sqnp in nqnp so na obeh rekah zelo podobna, le da so v Tolminu specifični odtoki približno dvakrat večji kot v Bači pri Modreju (slika 11, preglednica 2). Razloga za to sta vsaj dva: prvi je v količini padavin, ki ki se zmanjšujejo od zahoda proti vzhodu, zaradi česar porečje Bače prejme manj padavin kot porečje Tolminke. Drugi razlog pa je $\mathrm{v}$ domnevno napačno določenih razvodnicah obeh porečij v razmerju do Save Bohinjke, saj po vodnobilančnih izračunih na Tolminki odteče $16 \%$ preveč, na Bači pa $15 \%$ premalo vode (Kolbezen, Pristov 1998). Ocene pretokov na pritokih Tolminke in Bače 
so tako dokaj nezanesljive in so $\mathrm{v}$ veliki meri odvisne od tega, katero izmed omenjenih postaj bi privzeli za primerjalno. Morda bi bila najboljša rešitev, da bi pri ocenjevanju pretokov na njunih pritokih upoštevali srednje vrednosti specifičnih odtokov, dobljenih na osnovi podatkov z obeh postaj.

Slika 10: Vrednosti q, sqnp in nqnp za vodomerne postaje Cankova, Polana, Martjanci, Hodoš, Središce in Kobilje v obdobju 1971-2000

Figure 10: Values q, sqnp and nqnp for the Cankova, Polana, Martjanci, Hodoš, Središče and Kobilje gauging stations in the period 1971-2000

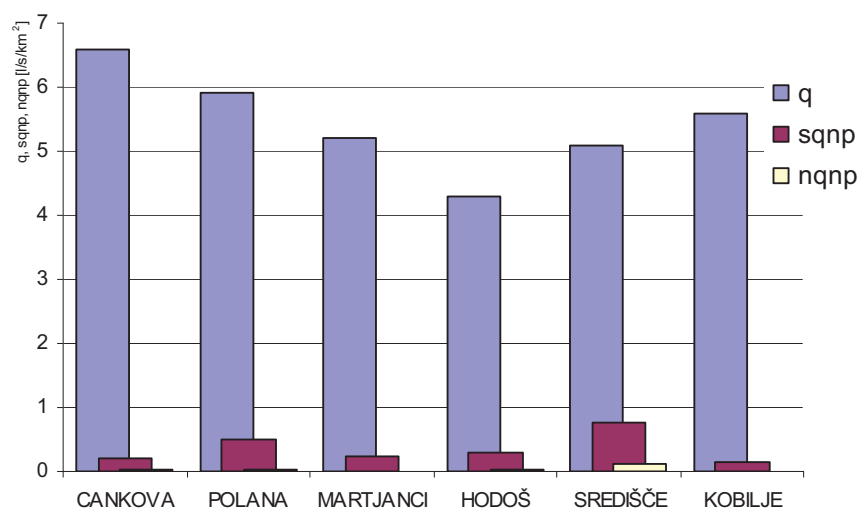

Vir/source: Arhiv sektorja za hidrologijo, urad za monitoring, Agencija RS za okolje

Slika 11: Vrednosti q, sqnp in nqnp za vodomerne postaje Tolmin, Bača pri Modreju, Kršovec in Kal-Koritnica v obdobju 1971-2000

Figure 11: Values q, sqnp and nqnp for the Tolmin, Bača pri Modreju, Kršovec and Kal-Koritnica gauging stations in the period 1971-2000

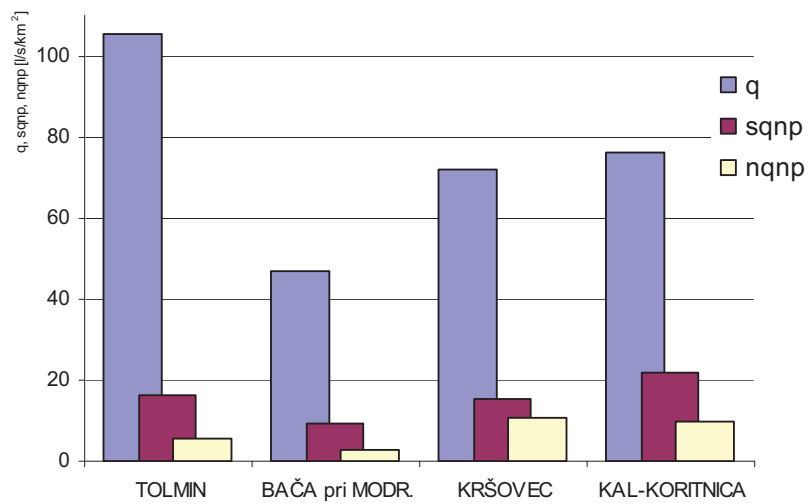

Vir/source: Arhiv sektorja za hidrologijo, urad za monitoring, Agencija RS za okolje 
Preglednica 2: Hidrološkeznačilnosti vzgornjih grafikonih (slike 8-11) obravnavanih vodomernih postaj v obdobju 1971-2000

Table 2: Hydrological characteristics of the above mentioned (Figures 8-11) gauging stations in the period 1971-2000

\begin{tabular}{|c|c|c|c|c|c|c|c|c|c|c|c|c|c|c|c|c|c|c|c|c|c|c|c|}
\hline 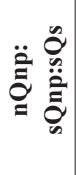 & 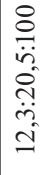 & 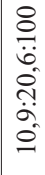 & 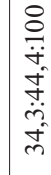 & 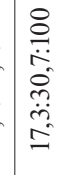 & 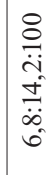 & $\begin{array}{l}\stackrel{̊}{0} \\
\ddot{0} \\
\tilde{\sigma} \\
\ddot{0} \\
i \\
i\end{array}$ & 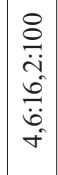 & 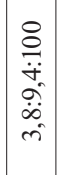 & $\mid \begin{array}{c}\stackrel{8}{0} \\
\ddot{a} \\
\tilde{n} \\
\stackrel{-}{-}\end{array}$ & 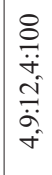 & $\begin{array}{l}8 \\
\ddot{0} \\
\dot{0} \\
\hat{\imath} \\
\ddot{0} \\
\dot{ \pm}\end{array}$ & 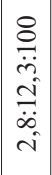 & 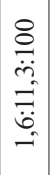 & $\begin{array}{c}8 \\
\stackrel{1}{0} \\
0 \\
\ddot{n} \\
\ddot{0}\end{array}$ & $\mid \begin{array}{c}8 \\
\stackrel{8}{*} \\
\dot{0} \\
\dot{\infty} \\
0 \\
0\end{array}$ & \begin{tabular}{c}
8 \\
\hdashline \\
$\infty$ \\
+ \\
$\dot{0}$ \\
0 \\
0
\end{tabular} & 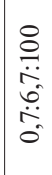 & $\begin{array}{l}8 \\
\stackrel{0}{0} \\
\dot{0} \\
\stackrel{n}{\dot{+}} \\
\dot{i}\end{array}$ & $\begin{array}{l}8 \\
0 \\
0 \\
0 \\
0 \\
0 \\
0 \\
0\end{array}$ & 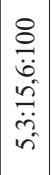 & 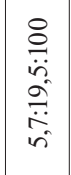 & 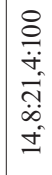 & 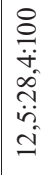 \\
\hline 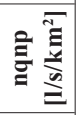 & 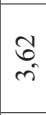 & $\begin{array}{l}\hat{\sigma} \\
\text { i }\end{array}$ & $\begin{array}{l}n \\
n \\
n\end{array}$ & Fु & $\begin{array}{l}n \\
i \\
i\end{array}$ & $\stackrel{\cong}{=}$ & $\underset{-}{0}$ & $\begin{array}{l}8 \\
0\end{array}$ & $\frac{ \pm}{0}$ & $\stackrel{2}{0}$ & $\stackrel{\vec{i}}{\vec{i}}$ & $\begin{array}{c}0 \\
0 \\
0 \\
0\end{array}$ & $\stackrel{7}{0}$ & $\begin{array}{l}\tilde{\theta} \\
\tilde{0}\end{array}$ & $\begin{array}{l}\tilde{O} \\
0 \\
0\end{array}$ & $\stackrel{8}{0}$ & $\delta_{0}^{0}$ & $\stackrel{\approx}{0}$ & $\stackrel{8}{8}$ & $\begin{array}{l}\overrightarrow{5} \\
i n\end{array}$ & $\stackrel{0}{:}$ & $\begin{array}{l}30 \\
\varrho\end{array}$ & مُ \\
\hline 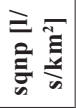 & $\begin{array}{l}\text { to } \\
0\end{array}$ & $\begin{array}{l}n \\
6 \\
\text { n. }\end{array}$ & $\begin{array}{l}\tilde{N} \\
\Omega\end{array}$ & $\stackrel{\text { ले }}{=}$ & $\begin{array}{l}\infty \\
\infty \\
+\end{array}$ & $\begin{array}{l}\bar{n} \\
n\end{array}$ & $\begin{array}{l}5 \\
6 \\
n\end{array}$ & $\stackrel{g}{\rightarrow}$ & $\mid \begin{array}{l}n \\
0 \\
0 \\
0\end{array}$ & $\begin{array}{l}\tilde{\sigma} \\
\text { i }\end{array}$ & $\begin{array}{l}8 \\
+\end{array}$ & $\stackrel{\infty}{\stackrel{\infty}{\sim}}$ & $\begin{array}{c}1 \\
\infty \\
0 \\
0\end{array}$ & $\begin{array}{l}\text { ते } \\
\text { ô }\end{array}$ & $\vec{n}$ & $\begin{array}{l}\varkappa \\
\tilde{o} \\
\tilde{0}\end{array}$ & సे & $\stackrel{0}{0}$ & $\stackrel{n}{0}$ & $\begin{array}{l}\mathfrak{7} \\
\text { of } \\
-\end{array}$ & $\frac{\infty}{\sigma}$ & $\begin{array}{l}\infty \\
\substack{n \\
n \\
n}\end{array}$ & $\frac{\sigma}{N}$ \\
\hline 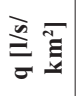 & ते & $\stackrel{\Delta}{\tilde{N}}$ & ma & $\overrightarrow{\tilde{n}}$ & $\begin{array}{l}n \\
\tilde{m}\end{array}$ & $\tilde{f}$ & $\hat{\tilde{i}}$ & $\begin{array}{l}\infty \\
n \\
n\end{array}$ & 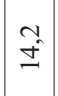 & $\begin{array}{l}n \\
0 \\
0\end{array}$ & $\begin{array}{l}0 \\
\therefore \\
\end{array}$ & $\begin{array}{l}+ \\
\stackrel{0}{0}\end{array}$ & $\hat{\therefore}$ & $\begin{array}{l}0 \\
0 \\
0\end{array}$ & in & in & $\stackrel{m}{f}$ & $\vec{n}$ & $\begin{array}{l}0 \\
i n\end{array}$ & $\begin{array}{l}n \\
\tilde{o} \\
0\end{array}$ & $\begin{array}{l}\stackrel{0}{r} \\
\stackrel{f}{f}\end{array}$ & $\begin{array}{l}\text { i } \\
\text { in }\end{array}$ & ڤָ \\
\hline 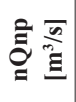 & $\begin{array}{l}n \\
0 \\
1 \\
0 \\
0\end{array}$ & $\frac{9}{9}$ & t? & 胥 & $\frac{1}{0}$ & 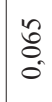 & $\begin{array}{l}0 \\
\tilde{\delta} \\
0 \\
0\end{array}$ & $\begin{array}{l} \pm \\
0 \\
0 \\
0\end{array}$ & 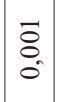 & $\begin{array}{l}0 \\
0 \\
0 \\
0\end{array}$ & $\frac{n}{0}$ & $\underset{\theta}{\vec{\theta}}$ & $\begin{array}{l}\tilde{y} \\
\tilde{\delta} \\
0 \\
0\end{array}$ & $\begin{array}{l}\overrightarrow{8} \\
\dot{0}\end{array}$ & $\begin{array}{l} \pm \\
8 \\
0 \\
0\end{array}$ & $\begin{array}{l}8 \\
:\end{array}$ & $\begin{array}{l}\tilde{\delta} \\
\tilde{O} \\
0\end{array}$ & $\overrightarrow{8}$ & $\begin{array}{l}8 \\
0 \\
0 \\
0\end{array}$ & 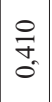 & مิ & 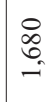 & 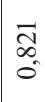 \\
\hline$\overline{\bar{z}} \overline{\bar{n}} \overline{\underline{n}}$ & $\underset{n}{n}$ & in & $\stackrel{\text { Iิ }}{\text { in }}$ & 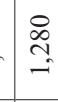 & $\begin{array}{c}\bar{m} \\
\text { o. }\end{array}$ & $\begin{array}{l}\tilde{m} \\
\text { m. }\end{array}$ & 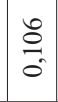 & $\begin{array}{l}0 \\
0 \\
0 \\
0\end{array}$ & $\begin{array}{l}0 \\
\vdots \\
0 \\
0\end{array}$ & 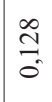 & $\frac{\infty}{m}$ & $\begin{array}{l}\tilde{T} \\
\sigma \\
0_{0}^{-}\end{array}$ & $\mid \begin{array}{l}\infty \\
\tilde{\pi} \\
\tilde{0} \\
0\end{array}$ & $\begin{array}{l}0 \\
\stackrel{2}{0} \\
0\end{array}$ & $\frac{0}{0}$ & o. & $\begin{array}{l}0 \\
\tilde{\delta} \\
0 \\
0\end{array}$ & \&. & $\begin{array}{l}\tilde{o} \\
0 \\
0\end{array}$ & $\begin{array}{c}\stackrel{8}{2} \\
\stackrel{1}{-}\end{array}$ & 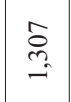 & 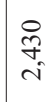 & $\begin{array}{l}8 \\
\infty \\
\infty \\
-1\end{array}$ \\
\hline$\hat{\partial} \overline{\hat{n}}$ & $\overrightarrow{\tilde{m}}$ & 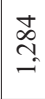 & $\begin{array}{l}\stackrel{\otimes}{\infty} \\
\stackrel{+}{f}\end{array}$ & $\stackrel{?}{\stackrel{?}{f}}$ & 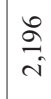 & $\begin{array}{l}n \\
\infty \\
i \\
i \\
c\end{array}$ & $\begin{array}{l}0 \\
0 \\
0 \\
0 \\
0\end{array}$ & 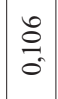 & $\frac{\vec{\sigma}}{0}$ & $\underset{-}{\stackrel{\delta}{-}}$ & $\stackrel{n}{\hat{\sigma}}$ & $\begin{array}{l}\hat{\delta} \\
\alpha \\
\sigma \\
\sigma\end{array}$ & $\begin{array}{l}0 \\
\stackrel{0}{i} \\
i\end{array}$ & 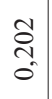 & 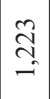 & 余 & 竎 & Iै & 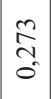 & $\stackrel{ }{\stackrel{2}{i}}$ & to & $\stackrel{?}{m}$ & \begin{tabular}{l}
8 \\
\multirow{0}{0}{} \\
6
\end{tabular} \\
\hline 离 & $\overrightarrow{\mathrm{f}}$ & हे & $\stackrel{\infty}{+}$ & & ర్రి & $\stackrel{0}{i n}$ & $\underset{\infty}{\infty}$ & & & 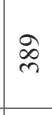 & $\underset{\sim}{\infty}$ & సે & 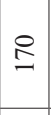 & ¿̊. & $\bar{\Omega}$ & $\stackrel{\infty}{\sim}$ & $\stackrel{\sim}{\text { กิ }}$ & & $\underset{\Phi}{ \pm}$ & $\stackrel{\infty}{\stackrel{\infty}{0}}$ & ț & ఠ̊ & $\stackrel{\leftrightarrow}{q}$ \\
\hline $\begin{array}{l}\overrightarrow{\bar{E}} \\
\stackrel{\bar{E}}{I}\end{array}$ & $\begin{array}{l}\mathbf{6} \\
\infty \\
\infty\end{array}$ & $\begin{array}{l}\infty \\
\infty \\
0 \\
0 \\
+\end{array}$ & $\begin{array}{l}8 \\
\stackrel{\Xi}{I}\end{array}$ & 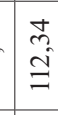 & $\begin{array}{l}\Re \\
\hat{6}\end{array}$ & $\begin{array}{l}n \\
\text { n. } \\
i n\end{array}$ & $\begin{array}{l}n \\
\infty \\
\infty \\
\infty \\
\sim\end{array}$ & $\underset{0}{\frac{N}{6}}$ & $\stackrel{ }{\sim}$ & శి & $\begin{array}{l}\hat{\sigma} \\
\hat{\sigma}\end{array}$ & \begin{tabular}{|c|}
8 \\
$\stackrel{8}{+}$ \\
$\stackrel{+}{+}$ \\
\end{tabular} & 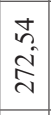 & $\begin{array}{l}q \\
\dot{q} \\
8 \\
\dot{n}\end{array}$ & $\begin{array}{l}\vec{\sim} \\
\infty \\
\stackrel{\sim}{\hat{~}}\end{array}$ & $\begin{array}{l}= \\
\infty \\
\infty\end{array}$ & $\begin{array}{l}\approx \\
\stackrel{2}{\varrho}\end{array}$ & $\underset{\infty}{\underset{\infty}{t}}$ & $\begin{array}{l}0 \\
\stackrel{0}{0} \\
\infty \\
+\end{array}$ & 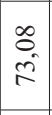 & $\begin{array}{l}\bar{m} \\
\tilde{f} \\
\mathcal{I}\end{array}$ & $\begin{array}{l}8 \\
\infty \\
\infty \\
2\end{array}$ & $\begin{array}{l}\Delta \\
\dot{0} \\
\infty\end{array}$ \\
\hline$\ddot{z}$ & 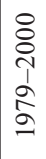 & 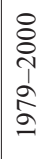 & 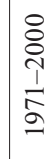 & 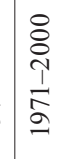 & 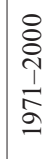 & 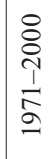 & 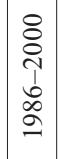 & 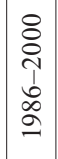 & 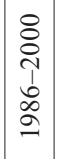 & 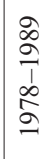 & $\begin{array}{l}\stackrel{2}{2} \\
\stackrel{2}{1} \\
\infty \\
\stackrel{\infty}{2} \\
\stackrel{2}{2}\end{array}$ & 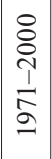 & 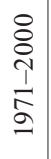 & 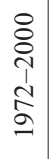 & 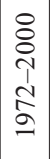 & 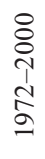 & 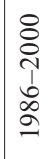 & 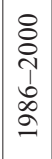 & 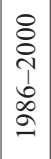 & 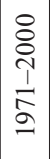 & 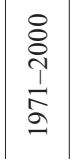 & 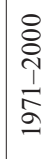 & 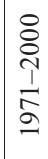 \\
\hline 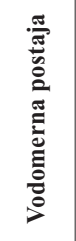 & مै & $\simeq$ & 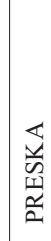 & 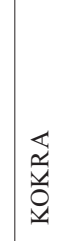 & 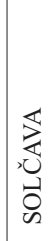 & ב્યુ & 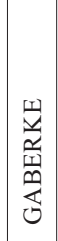 & 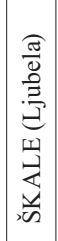 & 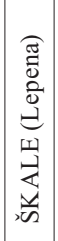 & 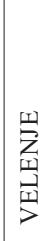 & 恐 & 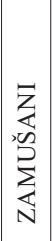 & 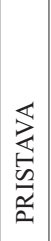 & 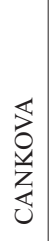 & 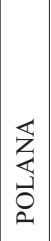 & 产 & 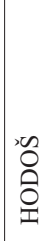 & 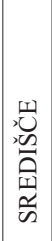 & 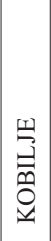 & 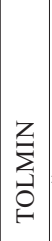 & 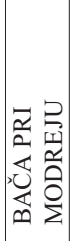 & 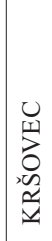 & 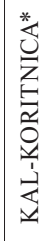 \\
\hline
\end{tabular}

* Pri vodomerni postaji Kal-Koritnica so odšteti pretoki kanala Roje, in sicer $0,42 \mathrm{~m}^{3} / \mathrm{s}$ od $\mathrm{s} Q \mathrm{~s}, 0,36 \mathrm{~m}^{3} / \mathrm{s} \mathrm{od}$ sQnp in 0,309 $\mathrm{m}^{3} / \mathrm{s}$ od $n$ Qnp.

Vir/source: Arhiv sektorja za hidrologijo, urad za monitoring, Agencija RS za okolje 
Vodomerni postaji Kršovec in Kal-Koritnica merita pretoke na Soči in njenem pritoku Koritnici. Reki odmakata pretežno kraško območje med Krnom, Triglavom, Vršičem, Mangartom in Rombonom. Porečji sta primerljivi po nadmorski višini in povprečni količini padavin, ki znaša nekako med 2600 in $3000 \mathrm{~mm}$ na letni ravni. Na Koritnici sta $q$ za $6 \%$ in sqnp za 41 \% večja kot na Soči, medtem ko je nqnp na Soči večji, in sicer za 11 \% (slika 11, preglednica 2). Primerjava nakazuje na podpovršinski odtok v Kršovcu, še posebej v času nizkih vodostajev. Del razlike lahko verjetno odpade tudi na le deloma izničen vpliv kanala Roje, katerega pretoke smo odšteli od originalnih vrednosti pretokov na Koritnici. Metoda ocenjevanja pretokov Soče na podlagi Koritnice in obratno bi dajala dokaj dobre rezultate za $s Q s$, zaradi podpovršinskega odtoka v Kršovcu (Kolbezen, Pristov 1998) bi s to postajo $s Q n p$ podcenili, dokaj dobro, a verjetno zgolj slučajno, bi ocenili tudi $n Q n p$.

Iz opisanih primerjav znotraj posameznih parov/skupin postaj je razvidno, da so v večini primerov $q$-ji med seboj dovolj podobni za ocenjevanje $s Q s$, medtem ko so med $s q n p$-ji in $n q n p$ ji za uspešno ocenjevanje $s Q n p$ in $n Q n p$ razlike navadno prevelike. Razlogi za razlike so od para do para (skupine) različni, navadno pa gre bodisi za prekratke primerjalne podatkovne nize, bodisi za podpovršinske odtoke na posameznih postajah, bodisi za nepravilno določene razvodnice, ali pa se dejavniki odtoka (nadmorska višina, relief, količina padavin, geološka zgradba, izhlapevanje, ...) spreminjajo na kratkih razdaljah in so zato razlike med bolj razmaknjenimi porečjih preprosto prevelike. Tudi razlike v površini porečij lahko znatno vplivajo na razlike v specifičnih odtokih, saj so le ti po toku navzdol praviloma vse manjši (Trobec 2007), zaradi česar je primerjava specifičnih odtokov v različno velikih porečjih otežena.

$\mathrm{Na}$ vodotokih, kjer ne razpolagamo s podatki vodomernih postaj, menimo, da lahko na območjih z dovolj gosto mrežo postaj, s primerjalno postajo, ki ima opazovalni niz daljši od dvajsetih let ter podobno veliko vodozbirno zaledje kot lokacija, za katero ocenjujemo pretoke, kot tudi podobne fizično- in družbenogeografske značilnosti površja, ki vplivajo na odtok, $s Q s$ ocenjujemo na $\pm 5 \%$ natančno, $s Q n p$ na $\pm 10 \%$ in $n Q n p$ na $\pm 20 \%$. Po drugi strani na območjih z manj gosto mrežo postaj, s primerjalno postajo, ki ima podatkovni niz krajši od dvajsetih let ter bistveno različno veliko vodozbirno zaledje kot lokacija, za katero ocenjujemo pretoke, kot tudi različne fizično- in družbenogeografske značilnosti površja, ki vplivajo na odtok, po našem mnenju $s Q s$ lahko ocenjujemo na $\pm 10 \%$ natančno, $s Q n p$ na $\pm 20 \%$, ocene $n Q n p$ pa so v tem primeru zgolj informativnega značaja - napako ocene ocenjujemo na $\pm 35 \%$, pri manjših vodotokih pa je ta lahko tudi $\pm 50 \%$ ali več.

Ocene obdobnih pretokov na vodotokih, kjer razpolagamo s podatki vodomernih postaj, spadajo med najzanesljivejše. Menimo, da $s Q s, s Q n p$ in $n Q n p$ na osnovnem vodotoku $\mathrm{v}$ neposredni bližini vodomerne postaje lahko ocenjujemo na $\pm 3 \%$ natančno.

$\mathrm{Na}$ odseku med dvema zaporednima postajama, ki imata znatno različne specifične odtoke, slednje, za lokacijo, na kateri pretoke ocenjujemo, navadno s pomočjo linearnih funkcij q, sqnp in nqnp tudi ocenimo (Trobec 2007). Zanesljivost ocene pri tovrstnem - na podatkih dveh postaj temelječem - ocenjevanju obdobnih pretokov je odvisna predvsem od relativne razlike med vrednostmi $q$, sqnp in $n q n p$ na izbranih postajah. Večje razlike pomenijo manjšo zanesljivost in obratno, manjše razlike pomenijo večjo zanesljivost ocene. Več kot je vodomernih postaj vzdolž toka in krajši kot so odseki brez podatkov o pretokih 
med njimi, zanesljivejše so interpolirane ocene specifičnih odtokov in posledično tudi ocene obdobnih pretokov $s Q s, s Q n p$ in $n Q n p$.

Zgornje navedbe o zanesljivosti ocen pretokov, dobljenih s hidrogeografskimi metodami, so ocenjene na podlagi izračunanih razlik v specifičnih odtokih znotraj posameznih predstavljenih parov/skupin vodomernih postaj. Poudariti velja, da so zgolj informativnega značaja in da je do njih potrebno zavzeti kritično distanco. Del razlik v specifičnih odtokih znotraj posameznih parov/skupin vodomernih postaj gre pripisati pomanjkljivosti (oziroma ponekod celo neustreznosti) metodologije hidrogeografskih metod ocenjevanja pretokov, ko specifične odtoke $\mathrm{z}$ enega območja apliciramo na nekem drugem območju, in $\mathrm{s}$ tem zanemarimo morebitne regionalne razlike v odtokih. Drugi del razlik pa gre pripisati samim napakam izvornih podatkov o pretokih. Ti se ob primerjavi specifičnih odtokov znotraj posameznih parov/skupin lahko bodisi izničijo bodisi seštejejo, odvisno od tega, ali so precenjeni ali podcenjeni. Tega vpliva pri našem ocenjevanju zanesljivosti ocen pretokov ne moremo predvideti.

\section{SKLEP}

Številni slovenskih vodotokih so izvzeti iz mreže opazovalnih postaj. Pri ocenjevanju njihovih obdobnih pretokov si lahko pomagamo s podatki o pretokih s primerjalnih vodomernih postaj z vodotokov v bližnjih porečjih, za katere predvidevamo, da imajo podobne značilnosti odtoka kot vodotoki, na katerih pretoke ocenjujemo.

Zanesljivosti ocen obdobnih pretokov so odvisne od številnih dejavnikov, med katerimi so najpomembnejši ustreznost izbire primerjalne vodomerne postaje, kakovost podatkov o pretokih za primerjalno vodomerno postajo ter dolžina podatkovnega niza.

Kakovost ocen obdobnih pretokov, ki jih dobimo s hidrogeografskimi metodami ocenjevanja, ni empirično preverljiva. S temi metodami ocenjujemo obdobne karakteristične pretoke $(s Q s, s Q n p, n Q n p, \ldots)$, navadno za obdobje tridesetih let, ki se jih z vzporednimi kontrolnimi dnevnimi, mesečnimi in tudi nekajletnimi kontinuiranimi meritvami pretokov na terenu praviloma ne da učinkovito preverjati. Za ocenjevanje zanesljivosti ocenjenih obdobnih pretokov je tako potrebno poseči po metodah posrednega preverjanja.

Preučili smo možnost, da bi ocene obdobnih pretokov preverjali s pomočjo podatkov o pretokih za opuščene vodomerne postaje in ugotovili, da ta možnost ni najprimernejša, saj imajo opuščene postaje navadno zastarele nize podatkov, ki se le v manjši meri (če sploh) prekrivajo s podatki kasneje vzpostavljenih postaj, zaradi česar je primerjava med njimi otežena. Podatkov z opuščenih vodomernih postaj pa pri ocenjevanju pretokov vseeno ne gre povsem spregledati, saj lahko v primeru večjih odstopanj med specifičnimi odtoki primerjalne vodomerne postaje ter bližnje opuščene postaje sklepamo na morebitno nepravilnost ocene.

Mreža vodomernih postaj je v Sloveniji z vidika ocenjevanja nemerjenih obdobnih pretokov razporejena precej racionalno, kar pomeni, da se vodomerne postaje le redko nahajajo hkrati na dveh oziroma več sosednjih vodotokih nižjega ranga. Slednje ima za posledico, da se informacije o specifičnih odtokih s sosednjih območij (kjer ni pričakovati večjih razlik v specifičnih odtokih) ne podvajajo, saj je možno iz specifičnih odtokov vodotoka A sklepati na specifične odtoke sosednjega vodotoka B. Kljub opisanemu dejstvu smo izluščili 10 parov/ 
skupin vodotokov, znotraj katerih smo primerjali domnevno podobne specifične odtoke in na podlagi dobljenih rezultatov podali oceno zanesljivosti ocenjevanja obdobnih pretokov s hidrogeografskih metodami. Ugotavljamo, da so ocene srednjih pretokov znatno zanesljivejše od ocen nizkih pretokov.

Menimo, da lahko na vodotokih, kjer ne razpolagamo s podatki vodomernih postaj, na območjih z dovolj gosto mrežo postaj, s primerjalno postajo, ki ima opazovalni niz daljši od dvajsetih let ter podobno veliko vodozbirno zaledje kot lokacija, za katero ocenjujemo pretoke, kot tudi podobne fizično- in družbenogeografske značilnosti površja, ki vplivajo na odtok, $s Q s$ ocenjujemo na $\pm 5 \%$ natančno, $s Q n p$ na $\pm 10 \%$ in $n Q n p$ na $\pm 20 \%$. Po drugi strani na območjih z manj gosto mrežo postaj, s primerjalno postajo, ki ima podatkovni niz krajši od dvajsetih let ter bistveno različno veliko vodozbirno zaledje kot lokacija, za katero ocenjujemo pretoke, kot tudi različne fizično- in družbenogeografske značilnosti površja, ki vplivajo na odtok, po našem mnenju $s Q s$ lahko ocenjujemo na $\pm 10 \%$ natančno, $s Q n p$ na $\pm 20 \%$, ocene $n Q n p$ pa so v tem primeru zgolj informativnega značaja - napako ocene ocenjujemo na $\pm 35 \%$, pri manjših vodotokih pa je ta lahko tudi $\pm 50 \%$ ali več.

\section{Viri in literatura}

ARSO GIS. Medmrežje: http://gis.arso.gov.si (14. 2. 2007).

Bat, M., Ulaga, F., Lalič, B., Frantar, P. 2003: Postopek za ocenjevanje $s Q n p\left(\mathrm{v} \mathrm{m}^{3} / \mathrm{s}\right)$ na lokacijah izpustov odpadnih voda $\mathrm{v}$ vodotoke (na osnovi določitve vodozbirnega zaledja in podatkov hidrološko primerljive vodomerne postaje $\mathrm{z}$ dovolj dolgim nizom opazovanja). Agencija RS za okolje (interno gradivo). Ljubljana.

Brilly, M., Šraj, M. 2005: Osnove hidrologije. Fakulteta za gradbeništvo in geodezijo. Ljubljana.

Brilly, M., Kobold, M. 1997: Minimalni pretoki voda v Sloveniji. Acta hydrotechnica 17, 107-114. Ljubljana.

Cegnar, T. 2003: Padavine. V: Vodno bogastvo Slovenije. Agencija RS za okolje. Ljubljana.

Foster, E. 1949: Rainfall and runoff. The MacMillan Company. New York.

Grad, K. 1974: Osnovna geološka karta SFRJ 1 : 100.000. Tolmač lista Kranj. Zvezni geološki zavod. Beograd.

Hidrološki letopis Slovenije 2000. Agencija RS za okolje. Ljubljana 2004.

Knapp, B. 1979: Elements of geographical hydrology. George Allen \& Unwin. London.

Kolbezen, M. 1998: Hidrografija Slovenije. V: Geografija Slovenije. Slovenska matica, Ljubljana.

Kolbezen, M., Pristov, J. 1998: Površinski vodotoki in vodna bilanca Slovenije. Ministrstvo za okolje in prostor, Hidrometeorološki zavod RS. Ljubljana.

Mioč, P., Žnidarčič, M., Hinterlechner-Ravnik, A., Rijavec, J., Ferjančič, L., Pleničar, M. 1977: Osnovna geološka karta SFRJ 1 : 100.000. Tolmač lista Slovenj Gradec. Zvezni geološki zavod. Beograd.

Newson, M. 1994: Hydrology and the river environment. Oxford University Press. Oxford.

Plut, D. 2000: Geografija vodnih virov. Oddelek za geografijo, Filozofska fakulteta. Ljubljana. 
Podatki o pretokih na vodomernih postajah v Sloveniji. Arhiv sektorja za hidrologijo, urad za monitoring, Agencija RS za okolje. Ljubljana.

Riđanović, J. 1993: Hidrogeografija. Školska knjiga. Zagreb.

Schumm, S. 1977: The fluvial system. John Wiley and Sons. Toronto.

Trobec, T. 2007: Hidrogeografske metode ocenjevanja nemerjenih pretokov v Sloveniji. Diplomsko delo, Oddelek za geografijo, Filozofska fakulteta. Ljubljana.

Trobec, T. 2008: Hidrogeografske metode ocenjevanja nemerjenih obdobnih pretokov v Sloveniji. Dela 29, 119-130. Ljubljana.

Uhan, J., Bat, M. (ur.). 2003: Vodno bogastvo Slovenije. Agencija RS za okolje. Ljubljana.

\section{RELIABILITY OF HYDROGEOGRAPHICAL METHODS OF ESTIMATING NON-MEASURED DISCHARGES IN SLOVENIA}

\section{Summary}

Numerous watercourses in Slovenia are not included in the gauging station network, therefore when estimating their discharges in a certain period, we rely on the discharge data of the gauging stations situated in the neighboring river basins, for which we can expect similar discharge characteristics to the watercourses for which the discharge is being measured.

The reliability of the discharge estimates depends on several factors, among the most important being the adequacy of the corresponding gauging station, the quality of the discharge data for the corresponding gauging station and the length of the data set.

The quality of the discharge estimates provided by the hydrogeographical estimation methods cannot be empirically verified. The methods are used to estimate characteristic discharges, typically for the period of 30 years, which cannot be verified by parallel control discharges in the field (neither daily, monthly nor annually). To estimate the reliability of the discharge estimates the methods of indirect control should be used.

We have examined the possibility of controlling the discharge estimates with the discharge data collected from the former gauging stations but the method has not proved to be the most appropriate as the data sets of the former gauging stations are usually not up-to-date and bear little or no resemblance to the data sets of the more recently established gauging stations, which makes a comparison fairly difficult. However, in cases of significant deviations of specific run-off between the gauging station and the former gauging station we can infer the possible anomaly in the estimates.

The gauging station network in Slovenia is dispersed rationally (from the point of view of estimating non-measured discharges), which results in the gauging stations rarely being positioned together on two or more neighboring watercourses of lower ranks. As a consequence, the information on specific run-off of the neighboring areas (where greater difference in specific run-off is not expected) is not duplicated, as we can infer the specific run-off of the neighboring watercourse B from the specific run-off of the watercourse A. Despite this fact we have identified 10 pairs/groups of watercourses, where we have compared supposedly similar specific run-off and, according to the results, estimated the reliability of the discharge estimates using the hydrogeographical estimation methods. We have come to 
the conclusion that the estimates of the average discharges are significantly more reliable than the estimates of the low discharges.

The estimates on the watercourses with no gauging stations can be estimated at $\pm 5 \%$ for average discharges, $\pm 10 \%$ for low discharges and $\pm 20 \%$ for the lowest discharges, considering the following facts: the network of gauging stations in the area is dense, the neighboring gauging station contains the data set longer than 20 years and covers a river basin of comparable size as the location where the discharge is being estimated, as well as it has similar physical and sociogeographic characteristics. On the other hand, the discharges in the areas with scarce network of gauging stations can be estimated at $\pm 10 \%$ for average discharges, $\pm 20 \%$ for low discharges and \pm 35 or even $50 \%$ for the lowest discharges, where the data set is shorter than 20 years, the size of the river basin of the neighboring gauging station is significantly different from the location where the discharge is being estimated, and physical and sociogeographic characteristics are not similar enough.

(prevod: Nina Sega) 